\title{
Ongoing population-level impacts on killer whales Orcinus orca following the 'Exxon Valdez' oil spill in Prince William Sound, Alaska
}

\author{
C. O. Matkin ${ }^{1,2}$, E. L. Saulitis ${ }^{1}$, G. M. Ellis ${ }^{3}$, P. Olesiuk $^{3}$, S. D. Rice ${ }^{4}$ \\ ${ }^{1}$ North Gulf Oceanic Society, 3430 Main St. Suite B1, Homer, Alaska 99603, USA \\ ${ }^{2}$ Alaska Sea Life Center, 301 Railway Avenue, Seward, Alaska 99664, USA \\ ${ }^{3}$ Department of Fisheries and Oceans, Pacific Biological Station, Nanaimo, British Columbia V9T 6N7, Canada \\ ${ }^{4}$ National Marine Fisheries Service, Auke Bay Laboratory, 11305 Glacier Highway, Juneau, Alaska 99801, USA
}

\begin{abstract}
Killer whales were photographed in oil after the 1989 'Exxon Valdez' oil spill, but preliminary damage assessments did not definitively link mortalities to the spill and could not evaluate recovery. In this study, photo-identification methods were used to monitor 2 killer whale populations $5 \mathrm{yr}$ prior to and for $16 \mathrm{yr}$ after the spill. One resident pod, the AB Pod, and one transient population, the AT1 Group, suffered losses of 33 and $41 \%$, respectively, in the year following the spill. Sixteen years after 1989, AB Pod had not recovered to pre-spill numbers. Moreover, its rate of increase was significantly less than that of other resident pods that did not decline at the time of the spill. The AT1 Group, which lost 9 members following the spill, continued to decline and is now listed as depleted under the Marine Mammal Protection Act. Although there may be other contributing factors, the loss of AT1 individuals, including reproductive-age females, accelerated the population's trajectory toward extinction. The synchronous losses of unprecedented numbers of killer whales from 2 ecologically and genetically separate groups and the absence of other obvious perturbations strengthens the link between the mortalities and lack of recovery, and the 'Exxon Valdez' oil spill.
\end{abstract}

KEY WORDS: Killer whales · 'Exxon Valdez' oil spill · EVOS · Southern Alaska · Fishery interactions · Residents · Transients

\section{INTRODUCTION}

On March 24, 1989, the supertanker 'Exxon Valdez' ran aground on Bligh Reef in northeastern Prince William Sound, Alaska, spilling 42 million liters of crude oil, the largest oil spill in USA history. Storms and currents eventually drove the oil through the western portion of the sound and westward to Kodiak Island and the Alaska Peninsula, nearly $900 \mathrm{~km}$ from the spill site (Loughlin 1994a).

The unprecedented research effort following the 'Exxon Valdez' oil spill (EVOS) resulted in a greater understanding of the long-term effects of large crude oil spills on species and on ecosystems (Loughlin 1994a, Rice et al. 1996, Peterson et al. 2003). However, detailed pre-spill censuses of free-ranging cetacean populations, such as those used in this study, are uncommon, and a lack of baseline data generally precludes the ability to assess damages caused by spills. Also, before the spill, little was known about the effects of oil on cetaceans because of the difficulty and ethical issues involved in conducting controlled experiments on whales in captivity and in finding carcasses, which often sink. From the few studies conducted prior to the spill, it was unclear whether free-ranging cetaceans would or could detect and/or avoid oil. Smith et al. (1983) found that captive bottlenose dolphins Tursiops truncatus initially avoided oiled areas in their tanks, but all eventually contacted the oil. Geraci \& St. Aubin (1985) provided evidence that while captive 
bottlenose dolphins relied on vision to detect thick oil, tactile response was the primary factor in avoidance. Smultea \& Wursig (1995) found that dolphins apparently did not detect sheen oil and that although they detected slick oil, they did not avoid traveling through it. Evans (1982) observed that gray whales Eschrichtius robustus typically swam through oil seeps off California. Although the gray whales modified their swim speeds and breathing rates, there was no consistent pattern of behavior in regard the presence of the oil. Lack of an olfactory system likely contributes to the difficulty cetaceans have in detecting oil.

Loughlin (1994a) included a number of studies evaluating the impact of the oil spill on cetaceans (e.g. Dahlheim \& Matkin 1994, Harvey \& Dahlheim 1994, Loughlin 1994b, Matkin et al. 1994, von Ziegesar et al. 1994). Dahlheim \& Matkin (1994) described a decline in the largest identified fish-eating 'resident' killer whale pod, AB Pod, but concluded that a direct link to the oil spill was equivocal. Effects on the genetically distinct mammal-eating 'transient' population, the AT1 Group, were not assessed.

In this paper, we examine the impact of the EVOS on killer whales based on long-term population monitoring. We examine the population trajectories of 2 groups of genetically and ecologically distinct killer whales in Prince William Sound to re-evaluate the confidence with which their decline and lack of recovery can be attributed to the EVOS. We examine the possible vectors for oil contamination in killer whales and assess their vulnerability to oil spills. Finally, we discuss the significance of our conclusions in light of previous observations and conclusions about the impact of oil on cetaceans.

\section{MATERIALS AND METHODS}

North Pacific killer whales. In contrast to most species in Prince William Sound, data were collected on killer whale numbers, social organization, distribution and population structure for $5 \mathrm{yr}$ prior to the oil spill, allowing accurate assessment of pre-spill population parameters. Since 1984, all groups frequently encountered in the Prince William Sound region have been censused annually in a longitudinal study based on the photo-identification of individuals (von Ziegesar et al. 1986, Leatherwood et al. 1990, Matkin et al. 1997, Matkin et al. 1999a). Similar studies have been carried out in the coastal waters of British Columbia and Washington State since the 1970s (Balcomb et al. 1982, Bigg et al. 1990, Ford et al. 2000). These long-term monitoring studies and detailed annual censuses of killer whale populations (von Ziegesar et al. 1986, Leatherwood et al. 1990, Matkin et al. 1997, 1999a) provide an unprecedented opportunity to examine long-term impacts of the EVOS on a top-level predator. Moreover, the population models developed from this and other long-term killer whale studies (e.g. Olesiuk et al. 1990, 2005, Matkin et al. 2003) provide a context for interpreting the impacts of oil spills on this species.

Association patterns developed from photographic data coupled with analysis of call types (Yurk et al. 2002) and genetic analysis from biopsy sampling (Barrett-Lennard et al. 1996) determined that killer whales in the northern Gulf of Alaska occur in 3 genetically, acoustically, morphologically and behaviorally distinct lineages: 2 types of fish-eating populations (so-called 'residents' and 'offshores'), and 1 type of mammaleating population (so-called 'transients') (Matkin et al. 1999a, Barrett-Lennard 2000, Ford et al. 2000, Saulitis et al. 2000, Yurk et al. 2002). Offshore whales are infrequently observed in our study area and were not considered in our analysis.

Resident killer whales in the coastal temperate eastern North Pacific, including Prince William Sound, travel in groups of related matrilines that exhibit no emigration or immigration of individuals between matrilines (Matkin \& Saulitis 1994, Matkin et al. 1999b) and feed primarily on salmonids (Ford et al. 1998, Saulitis et al. 2000); in our region, mostly on coho salmon Oncorhynchus kisutch and chinook salmon Oncorhynchus tshawytscha (Saulitis et al. 2000, C. O. Matkin unpubl. data). Groups of matrilines that travel together a majority of the time are termed 'pods' (Bigg et al. 1990). Pods occasionally may split along matrilineal lines to form new pods (Matkin et al. 1999b). Killer whales are long-lived. In southern Alaska, resident killer whales that survive to 6 mo of age (neonate mortality may be high, but difficult to measure) have an average life expectancy of $39.4 \mathrm{yr}$ for females and $31.4 \mathrm{yr}$ for males, with maximum longevities of about 60 to $70 \mathrm{yr}$ for females and 50 to $60 \mathrm{yr}$ for males (Matkin et al. 2003). In our study, the 11 resident pods that were consistently re-sighted over the study period were comprised of 4 to 45 (mean $=16.9$ ) ind. The most frequently encountered and largest pod prior to the spill was AB Pod, which contained 35 whales when first enumerated in 1984 and had 36 members in 1988 prior to the spill. Insofar as sample sizes permit, we assess the impact of EVOS by comparing the demographics within $\mathrm{AB}$ Pod before and after EVOS, and by contrasting the demographics of $\mathrm{AB}$ Pod with the other 'control' pods that were not impacted by the spill.

Transient groups often number fewer than 7 whales and are also composed of one or more matrilines (Matkin et al. 1999a). However, transient killer whale populations are not structured in permanent associations, or pods, as are resident populations. In most 
transient populations, immigration and emigration of individuals between groups does occasionally occur (Ford \& Ellis 1999, Baird \& Whitehead 2000). In Prince William Sound, the most commonly encountered transient killer whales are members of the AT1 Group, a genetically and socially isolated population which numbered 22 ind. at the beginning of the study in 1984 and 22 ind. in 1988 prior to the spill. During this period they traveled in small groups with strong association patterns, sometimes joining into larger associations. Currently they are considered by the National Marine Fisheries Service as a separate killer whale stock (Angliss \& Outlaw 2006) and listed as depleted under the Marine Mammal Protection Act. The AT1 whales feed primarily on the harbor seal Phoca vitulina and Dall's porpoise Phocoenoides dalli (Saulitis et al. 2000, Heise et al. 2003). This population is behaviorally and genetically isolated from the larger Gulf of Alaska transient population, whose members are seen infrequently in Prince William Sound and Kenai Fjords (Matkin et al. 1999a, Saulitis et al. 2005, Maniscalco et al. 2007) and, thus, cannot be used as a 'control' group, so our assessment is based on demographics before and after EVOS.

Fieldwork. Fieldwork for all study years from 1984 to 2005 occurred primarily between April and October of each year and was completed from a variety of small vessels (all less than $15 \mathrm{~m}$, most less than $12 \mathrm{~m}$ ) powered by either gasoline outboard or diesel inboard engines. Effort was centered in the western Prince William Sound region until the mid 1990s, when the effort was split between western Prince William Sound and the adjacent Kenai Fjords (Fig. 1). Surveys were not systematic, but focused on areas of known concentration, and the research vessel responded to reports of killer whale sightings. On an annual basis, researchers attempted to maximize the number of contacts with each killer whale pod or group with the goal of obtaining sufficient photographs to determine presence or absence of each member. Photographs for individual identification were taken of the left side of each whale, capturing details of the dorsal fin and saddle patch at no less than $1 / 1000 \mathrm{~s}$, initially using Illford HP5 and later Fuji Neopan 1600 high-speed black and white film. A single-lens reflex camera system was used, most recently a Nikon F-100 camera and a fixed $300 \mathrm{~mm}$ f4.5 auto focus lens. A $1.7 \times$ Nikon teleconverter was added when whales were difficult to approach closely and lighting was sufficient. When whales were encountered, researchers systematically moved from 1 subgroup (or individual) to the next, keeping track of the whales photographed. If possible, individual whales were photographed several times during each encounter to ensure an adequate identification photograph.
In long-term studies from this and other areas of the North Pacific, resident killer whales missing from their matrilines during repeated encounters have never returned, nor have they appeared in other pods or matrilines (Matkin et al. 1999b, 2003, Ford et al. 2000). Since resident matrilineal groups always travel as a unit, it is an accepted practice in the eastern North Pacific to assume that resident whales missing over several encounters spanning 1 yr or more are dead (Balcomb et al. 1982, Bigg et al. 1990, Matkin et al. 1999b). We used these criteria for determination of mortalities within resident pods.

Since the entire population of AT1 transients is encountered and photographed regularly, if not annually, mortalities and movement between groups of AT1 whales could be determined more readily than for other transient populations (Ford \& Ellis 1999, Baird \& Whitehead 2000). However, because of some potential for exchange of individuals among groups, mortalities could not be confirmed as quickly as for residents. In this study, we considered members of the AT1 Group to be certain mortalities if they had been missing from the population for $4 \mathrm{yr}$ or more based on analysis of our re-sighting data (see 'Results').

Recruitment in residents or transients was determined by the presence of a new calf alongside an adult female. Most calves were born in late fall or winter and not observed until spring when they were approximately 6 mo old. The births thus represent viable calves that survived to 6 mo of age, and do not include stillbirths or neonate mortality. When a pod or group was not encountered or completely photographed in a given year, deaths were amortized equally across the years between encounters and births assigned to a year (or in some cases amortized over several years) based on pod size when first encountered.

Ages were estimated for the killer whales described in this study and were determined by criteria used by Olesiuk et al. (1990, 2005) and Matkin et al. (2003): (1) Whales born during the study were aged on basis of year first observed as new calves or, if not seen in the year of births, by their size when first observed. (2) Males that were juveniles when first seen but too large to estimate based on size were aged by subtracting mean age of onset of sexual maturity (13 yr, Olesiuk et al. 1990, 2005) from the year the dorsal fin began to grow. (3) Males that were sexually but not physically mature when first seen were aged by subtracting mean age of onset of physical maturity (19 yr) from the year by which the dorsal fin was fully developed. (4) Males that were physically mature when first seen were aged on basis of the year they were first seen (these are considered minimum ages). (5) Females that were juvenile size when first seen were aged by subtracting mean age at first birth 


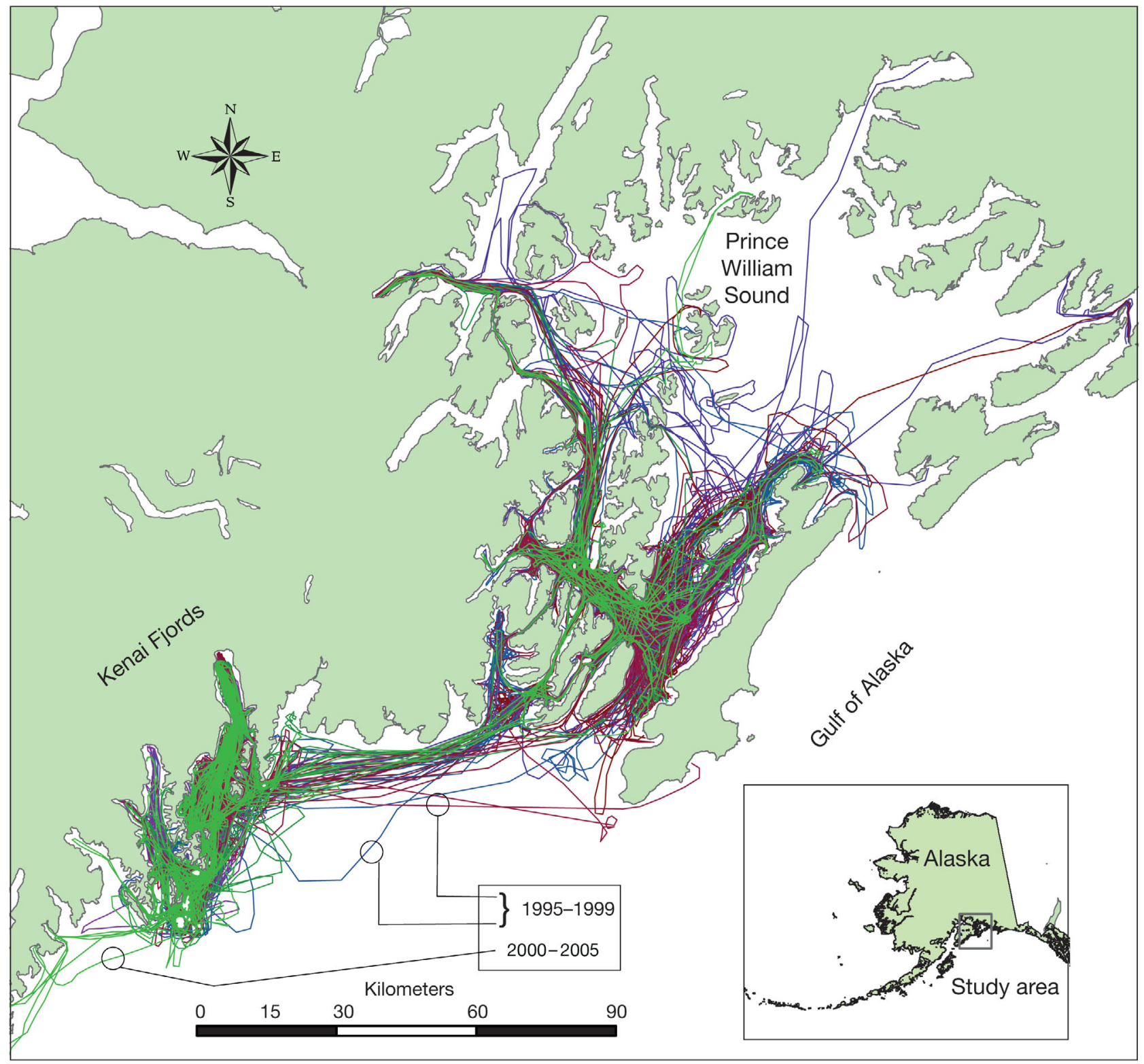

Fig. 1. The study area with a representation of effort between 1995 and 2005 (survey tracks)

(15 yr) from year they gave birth to their first viable calf. (6) Females that were adult size when first seen were also aged by subtracting mean age at first viable birth (15 yr) from year of birth of oldest known calf, but an adjustment was applied to account for the fact that these females may have given birth but lost viable offspring prior to the start of the study. (7) Whales that were approaching adult size when first seen but died before maturing were aged based on their size when first seen (these are considered crude ages $\pm 3 \mathrm{yr}$ ). (8) Juveniles that were born prior to the study and died before maturing were aged based on growth and estimated size during the study (crude ages $\pm 3 \mathrm{yr}$ ). Given the lack of dispersal from resident matrilineal groups, the estimated ages of resident whales, except for the oldest animals, are fairly accurate (see Olesiuk et al. 2005). AT1 Group whales were aged using the same criteria, although these estimates may be less accurate because genealogies were less certain.

Bullet wounds were determined by close visual inspection of high quality black-and-white photographs under a stereoscope. Wounds were indicated by round dark areas surrounded by light scar tissue; they were unlike any natural marks, scratches or wounds, although they varied in size and definition. 


\section{RESULTS}

\section{Survey effort across years}

Surveys conducted between 1984 and 2005 were extensive, covering a total of $212153 \mathrm{~km}$ on $2404 \mathrm{~d}$ and yielding 1257 encounters with killer whales. An average (mean $\pm \mathrm{SD}$ ) of $9224 \pm 4227 \mathrm{~km}$ were traveled each field season during $105 \pm 52 \mathrm{~d}$ of effort $\mathrm{yr}^{-1}$ with $55 \pm 22$ encounters $\mathrm{yr}^{-1}$. Although the number of encounters with killer whales per unit effort varied annually, it generally required a minimum $60 \mathrm{~d}$ to photo-identify the individuals and groups tracked in the study. However, even with effort of more than $100 \mathrm{~d} \mathrm{yr}^{-1}$, there were a few years in which we did not encounter all 11 pods.

\section{AB Pod}

In 1984, at the beginning of the study, we photoidentified 35 ind. in $\mathrm{AB}$ Pod. The pod declined to 31 ind. in 1987 (11\% over $3 \mathrm{yr}$ ) before recovering to 36 whales prior to the oil spill in the fall of 1988 (Fig. 2a). In the 7 other closely monitored pods that center their range in the northern Gulf of Alaska, there was a parallel decline from 82 whales in 1984 to 77 whales in 1987 ( $6 \%$ over 3 yr), followed by a recovery to 82 whales in 1988. The 3 resident pods most commonly found in southeastern Alaska, AG, AF05, AF22, did not decline in number during that period and increased from 39 whales in 1984 to 47 whales in 1988.

By 1986, depredations on the sablefish long-line fishery by killer whales in Prince William Sound were well-documented (Dahlheim \& Matkin 1994). Fishermen apparently defended their catch through various means, including shooting at the whales. Bullet wounds were photographed on a total of 13 AB Pod individuals in 1985 and 1986, but no new wounds were seen following implementation of 1986 federal regulations that made shooting killer whales in defense of fishing gear illegal (Table 1). Of the wounded whales, 4 died between 1985 and 1987, including 1 adult male, 1 juvenile of unknown sex and 2 older females that were possibly post-reproductive (Matkin et al. 1999a,b). Four wounded whales were among those that died in 1989 following the oil spill, 3 died in the mid-1990s, and 2 were still alive as of 2005 (Table 2). The fishery was closed in September 1988, at which time all 36 members of the pod were photo-documented. It remained closed throughout the winter of 1988-1989 and was still closed at the time of the oil spill in March 1989. Due to the spill, the sablefish fishery opening was delayed until June 12, 1989, and
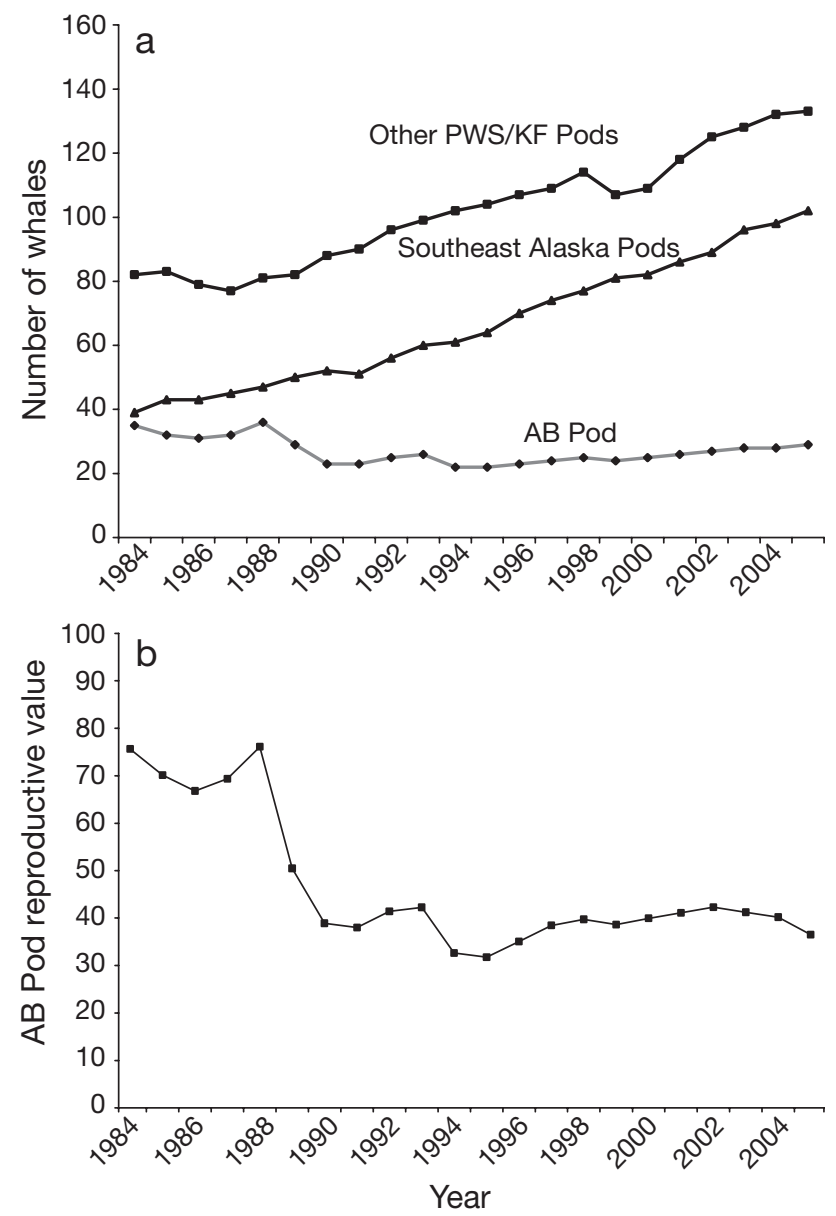

Fig. 2. Orcinus orca. (a) Number of resident killer whales in AB Pod, 7 other Prince William Sound/Kenai Fjords (PWS/KF) pods and 3 southeastern Alaska pods from 1984 to 2005. All pods are from the southern Alaska resident population. (b) Reproductive potential of $\mathrm{AB}$ Pod based on size and the age- and sex-structure of the pod before and after the 'Exxon Valdez' oil spill. Calculated from data in this study using methods detailed in Olesiuk et al. $(1990,2005)$ and Matkin et al. (2003)

there were no depredations or interactions reported or observed during the period. No new bullet wounds were documented between 1986 and 2005.

Exposure to oil was unequivocally documented by photo-identification of most of the remaining individuals from $A B$ Pod observed swimming through heavy sheens in southwestern Prince William Sound $6 \mathrm{~d}$ after the spill (March 31, 1989). Seven of the 36 AB Pod whales that had been photographed in the fall of 1988 were missing at that time. Another 6 ind. disappeared from $\mathrm{AB}$ Pod during the following winter (Table 2). These 13 deaths included 2 juvenile males, 6 juveniles of unknown sex, and 5 reproductive-age females, 3 of which had recently matured. This represents a mortality loss of $33 \%$ by the summer following the spill, which falls well outside the crude annual mortality 
Table 1. Orcinus orca. AB Pod whales that received apparent bullet wounds between 1985 and 1986, the life stage (when wounded) and sex of each whale, the year it was wounded, the year it died, and its estimated age at death. juv: juvenile; ad: adult. For those whales with a year range given for 'wounded' it is assumed that it was wounded during the winter, when regular observations were not made. ${ }^{* *}$ Whale was alive in 2005

\begin{tabular}{|c|c|c|c|c|c|c|c|c|c|c|c|c|c|}
\hline Whale & AB1 & AB3 & $\mathrm{AB} 4$ & $\mathrm{AB7}$ & AB16 & AB17 & AB18 & AB21 & AB25 & AB28 & AB30 & AB31 & AB34 \\
\hline Life stage \& sex & $\operatorname{ado}$ & ado & ado & ado & juvo & adọ & juvo & adọ & juvo & juv & juv & adọ & adọ \\
\hline Wounded & 1985 & 1985 & $1985-86$ & 1985 & 1985 & 1985 & 1985 & 1985 & 1986 & 1985 & $1985-86$ & 1985 & 1985 \\
\hline Died & 1986 & 1996 & 1996 & 1986 & 1994 & $* *$ & 1989 & 1989 & $* *$ & 1987 & 1989 & 1989 & 1985 \\
\hline Age & 25 & 30 & 30 & 28 & 19 & 49 & 8 & 29 & 34 & 16 & 13 & 17 & 29 \\
\hline
\end{tabular}

Table 2. Orcinus orca. Life stage and sex (if known), date of bullet wound (if any), estimated age and year of AB Pod mortalities in the 18 mo following the 'Exxon Valdez' oil spill. Abbreviations as in Table 1

\begin{tabular}{|c|c|c|c|c|c|c|c|c|c|c|c|c|c|}
\hline & AB8 & AB13 & AB18 & AB19 & AB20 & AB21 & AB23 & AB30 & AB31 & AB36 & AB37 & AB42 & AB44 \\
\hline $\begin{array}{l}\text { Life stage and Sex } \\
\text { Wounded }\end{array}$ & adọ & juvo $0^{7}$ & $\begin{array}{l}\text { juv } \\
1985\end{array}$ & juv $o^{1}$ & ado & $\begin{array}{l}\text { ado } \\
1985\end{array}$ & adọ & $\begin{array}{c}\text { juv } \\
1985-86\end{array}$ & $\begin{array}{l}\text { ado } \\
1985\end{array}$ & juv & juv & juv & juv \\
\hline Died & 1990 & 1989 & 1989 & 1990 & 1990 & 1989 & 1989 & 1989 & 1989 & 1990 & 1989 & 1989 & 1990 \\
\hline Age & 17 & 13 & 7 & 12 & 18 & 29 & 17 & 13 & 17 & 4 & 3 & 2 & 2 \\
\hline
\end{tabular}

Table 3. Orcinus orca. Comparison of the expected and observed births and deaths in AB Pod; expected number based on the sex- and age-structure of the pod (updated with data from this study using the methods outlined in Matkin et al. 2003)

\begin{tabular}{|c|c|c|c|c|c|c|c|c|c|c|c|c|c|c|c|c|c|c|c|c|c|c|}
\hline & $\begin{array}{l}\stackrel{H}{ } \\
\stackrel{\infty}{\rightarrow}\end{array}$ & $\begin{array}{l}\stackrel{1}{ } \\
\infty \\
\stackrel{9}{\rightarrow}\end{array}$ & $\begin{array}{l}\stackrel{0}{ } \\
\infty \\
\stackrel{2}{\rightarrow}\end{array}$ & $\begin{array}{l}\underset{\alpha}{\infty} \\
\stackrel{\infty}{\sigma}\end{array}$ & $\begin{array}{l}\infty \\
\infty \\
\infty \\
\stackrel{-}{\longrightarrow}\end{array}$ & $\begin{array}{l}\stackrel{9}{\infty} \\
\stackrel{\infty}{\mathscr{G}}\end{array}$ & $\stackrel{\text { 吕 }}{\rightarrow}$ & $\stackrel{\vec{\sigma}}{\sigma}$ & ๙ָ & $\stackrel{\mathscr{S}}{\mathscr{S}}$ & 苛 & $\begin{array}{l}\stackrel{2}{\circ} \\
\stackrel{9}{\rightarrow}\end{array}$ & $\stackrel{\mathscr{D}}{\mathscr{S}}$ & $\stackrel{\leftrightarrow}{\circ}$ & $\begin{array}{l}\infty \\
\stackrel{\infty}{\mathscr{S}} \\
\stackrel{-}{\sim}\end{array}$ & $\stackrel{\text { 吕 }}{\rightarrow}$ & $\begin{array}{l}\text { ঃ } \\
\text { ㄱ }\end{array}$ & ¿্ঠ) & ণ্ণ & ஜ্ণ & ঠ্ণ & $\begin{array}{l}\stackrel{2}{\circ} \\
\stackrel{\text { Oे }}{ }\end{array}$ \\
\hline \multicolumn{23}{|l|}{ Births } \\
\hline Expected & 2.6 & 2.1 & 2.2 & 2.5 & 2.0 & 1.2 & 1.3 & 1.4 & 1.4 & 1.8 & 1.4 & 1.2 & 1.4 & 1.4 & 1.3 & 1.4 & 1.3 & 1.3 & 1.5 & 1.2 & 1.2 & 0.9 \\
\hline Observed & 0 & 0 & 2 & 2 & 5 & 0 & 0 & 1 & 2 & 1 & 1 & 0 & 2 & 2 & 1 & 1 & 1 & 2 & 1 & 1 & 0 & 0 \\
\hline \multicolumn{23}{|l|}{ Deaths } \\
\hline Expected & - & 0.5 & 0.5 & 0.5 & 0.6 & 0.4 & 0.4 & 0.4 & 0.4 & 0.5 & 0.4 & 0.4 & 0.5 & 0.5 & 0.5 & 0.4 & 0.5 & 0.5 & 0.5 & 0.6 & 0.6 & 0.6 \\
\hline Observed & - & 3 & 4 & 0 & 1 & 8 & 5 & 1 & 0 & 0 & 5 & 0 & 1 & 1 & 0 & 2 & 0 & 1 & 0 & 1 & 0 & 1 \\
\hline
\end{tabular}

rates typically observed in other pods (mean $=2.5 \%$; $95 \%$ confidence interval $[\mathrm{CI}]=1.8$ to $3.2 \%$ ). Indeed, for the 10 other pods monitored during the study period, there have only been 2 other instances in which annual mortality exceeded $20 \%$, both involving very small pods that lost 2 ind. in the same year. The 13 deaths in $\mathrm{AB}$ Pod in the year of and the year following EVOS was 18 times the number expected ( 0.74 deaths) over this time span based on its sex- and age-structure (Table 3).

Additional mortalities in AB Pod after 1990 may be linked to mortalities that occurred in the year following the oil spill. Three reproductive females (AB23, AB8, and AB31) that died at the time of the spill left juveniles, AB36, AB41, AB38, respectively, which were $\leq 3 \mathrm{yr}$ of age. All 3 of these orphans eventually died, one in 1990 and the other 2 in 1994. Other mortalities after 1990 included one recently matured male, AB29, estimated to be $23 \mathrm{yr}$ of age, who died in 1991; and AB16, a female approximately $19 \mathrm{yr}$ of age and the last adult whale in her matriline, died in 1994 and left a juvenile born in 1991, AB45. Additionally, 2 killer whales whose fins collapsed at the time of the spill, the adult males AB2 and AB3, died in 1994 and in 1996, respectively.

The mortality patterns of resident killer whales conforms with the classic mammalian U-shape curve (Olesiuk et al. 1990, 2005, Matkin et al. 2003), with young calves and the oldest mature males and postreproductive females exhibiting the highest natural mortality, and adolescents and reproductive females exhibiting very low natural mortality. In contrast, many of the whales that died in $\mathrm{AB}$ Pod following EVOS tended to be older juveniles or young adults (Table 2).

Following the spill, AB Pod was less productive than other resident pods, although it fed on the same salmon prey as the other pods (Saulitis et al. 2000). From 1990 to 2005, there was a net increase of 6 whales in AB Pod, from 23 to 29 ind., an annual increase of about $1.6 \%$. Other Prince William Sound/Kenai Fjords pods and the southeastern Alaska pods did not decline during the oil spill, and from 1990 to 2005, increased at twice the rate of $\mathrm{AB}$ Pod $($ mean $=3.2 \% ; 95 \% \mathrm{CI}=1.94$ to $4.36 \%$ ). Indeed, all of the other resident pods ex- 
hibited greater rates of increase than AB Pod, with the exception of AI Pod, the smallest pod (comprising 6 whales), which showed no net change in size. Since 1990, the AB Pod females that survived EVOS have produced nearly as many calves as would be expected based on the number of females and their ages (16 births observed versus 20 births expected) (Table 3). The lack of recovery of $\mathrm{AB}$ Pod thus can be largely attributed to the loss of young adult females, which reduced the number of reproductive females by half (from 6 to 3), and the loss of juveniles, such that fewer animals matured to replace the reproductive females that died. As a result, the annual birth rate in AB Pod since the EVOS has been about $70 \%$ the birth rate observed in other resident pods, which was significantly lower than expected (Student's $t$-test; $t_{17,169}=1.88 ; \mathrm{p}=$ 0.035). This is also reflected by a sharp decrease in reproductive potential (number of calves expected to be born during the next generation) for AB Pod (Fig. 2b), which was significantly higher before (1984 to 1988) than after (1989 to 2005) the EVOS (Student's $t$-test; $t=16.5, \mathrm{p}<0.001)$.

The structure of $A B$ Pod also changed in the years following the oil spill. A sub-pod, named for the matriarch AB25 and consisting of 11 ind. in 1989, began to travel separately from the rest of AB Pod. The AB25 sub-pod lost 3 of its members in the year after the spill, including a reproductive female, a juvenile, and a calf. Since 1994, the sub-pod has traveled consistently with AJ Pod. While pods may split along matrilineal lines to form new pods, no sub-pod had been previously documented to travel with another pod on such a consistent basis. Despite traveling with AJ pod for over a decade, the AB25 sub-pod still uses calls unique to the AB Pod dialect (Yurk et al. 2002, Yurk 2005).

\section{AT1 Group}

In 1984 we identified 22 whales in the AT1 Group and the number remained constant until 1989. At the beginning of the study, 10 of these whales were adult males (based on dorsal fin size), 2 were maturing males and 2 were sub-adults of unknown sex. There were 6 potentially reproductive females and only 2 juveniles estimated to be $<5$ yr of age: AT10 was born around 1980, and AT3 was a new calf in 1984. The percentage of adult males in the population, $45 \%$, was much higher than the approximately 19 to $23 \%$ observed in sympatric resident populations (Olesiuk et al. 1990, 2005, Matkin et al. 2003). Since 1984 there has been no recruitment of new calves into this population, although killer whale births generally occur in winter months and it is conceivable non-viable calves were born that died before they were documented.
Exposure of AT1 individuals to oil was documented by photographic identification of 4 whales swimming through oil next to the 'Exxon Valdez' tanker less than $24 \mathrm{~h}$ after it ran aground (Fig. 3). Three of the 4 identified ind., AT5, AT7, and AT8, were missing the following year and eventually designated as mortalities.

Since the beginning of our study in 1984, AT1 whales have never been observed in coastal areas outside Kenai Fjords and Prince William Sound (Matkin et al. 2003, Saulitis et al. 2005), despite substantial observational effort in adjacent regions, including southeastern Alaska, Kachemak Bay, and Kodiak Island waters (Matkin et al. 1999a, 2007). Because of their limited range and association patterns, the entire AT1 Group has been regularly photographed since the study's inception. However, because transient social structure is more fluid, and groups or individuals may split and travel separately, establishing mortality is not as straightforward as it is for residents. We used our photographic database to determine that in $21 \%$ of the cases in which an AT1 whale went unphotographed for $1 \mathrm{yr}$, it was later re-sighted; in $3 \%$ of the cases in which an AT1 whale was not photographed for 2 consecutive yr, it was later re-sighted; and in only $0.4 \%$ of the cases in which an AT1 whale was missing for $3 \mathrm{yr}$ was it later re-sighted. No AT1 whale missing for $4 \mathrm{yr}$ was ever re-sighted, and it was considered dead.

A total of 9 of the 22 whales in the AT1 Group disappeared during the winter following the 1989 spill (Table 4). None of the 9 missing AT1 whales was resighted in the following $17 \mathrm{yr}$, and all are considered dead. These mortalities were of both sexes and various age classes, including 2 reproductive-age females and 2 near reproductive-age whales of unknown sex (Table 4). In 1989-1990, 2 whales genetically assigned to the AT1 Group became stranded and died in Prince William Sound, one of which was visually identified as AT19. Another male, AT11, approximately 28 yr old, was last seen in 1990, and a reproductive age female, AT12, was last seen in 1991, leaving 11 whales in the population by the mid-1990s. There were no additional mortalities until 2000, when the male AT1, approximately 33 yr old, became stranded and died near Cordova, Alaska. In 2002, 2 other AT1 adult males often seen in association with each other disappeared. AT13 was estimated to be at least $43 \mathrm{yr}$ old, and AT17 was estimated to be at least $38 \mathrm{yr}$ old. From mtDNA analysis, it was determined that one of these males was stranded on Hinchinbrook Island in 2002. Another male, AT14, a frequent associate of the AT1 Group, disappeared in 2003 at an estimated age of $41 \mathrm{yr}$. It is believed that this whale became stranded on Latouche Island in spring 2003, although genetic analysis from the carcass could not rule out the possibility that the 


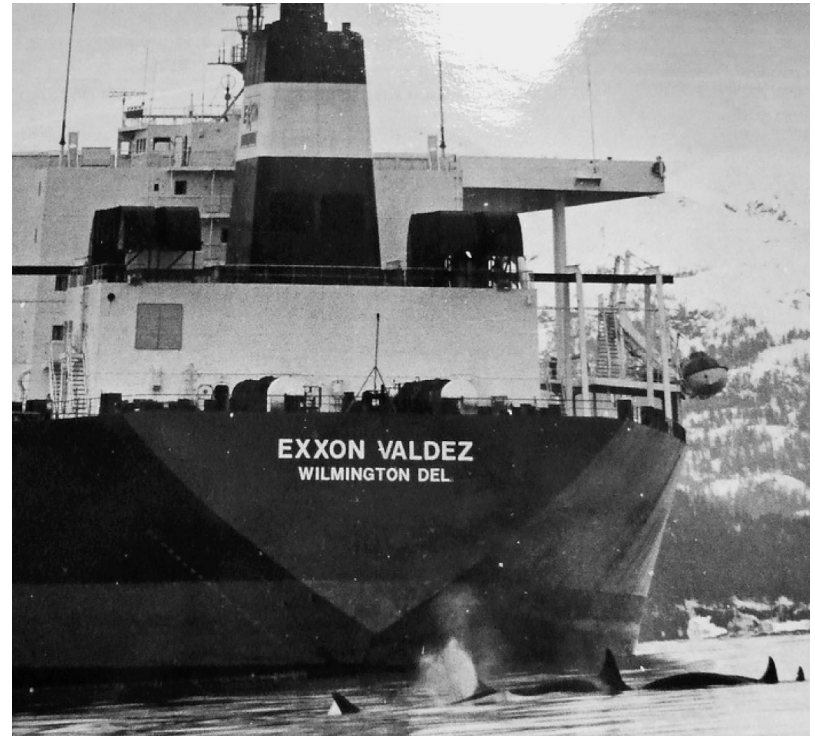

Fig. 3. Orcinus orca. Four members of the AT1 Group near the 'Exxon Valdez' less than $24 \mathrm{~h}$ after the oil spill.

Photo: Rosemary Kaul/Los Angeles Times

stranded whale was the missing AT13 (Vos et al. 2006). By 2005, the AT1 Group numbered no more than 8, and possibly only 7 , individuals. Mortalities since 2000 have been among older males and therefore are not unexpected, in contrast to the reproductive-age whales that disappeared following the spill.

\section{DISCUSSION}

Based on initial observations in the first few years following the EVOS, Dahlheim \& Matkin (1994) suggested that increased mortality in the AB Pod may have been attributable to the spill. Annual monitoring over the $16 \mathrm{yr}$ following 1989 strengthened the case that oil was responsible for the deaths observed in AB Pod as well as AT1 Group in the year following the spill. The concurrent mortalities in the 2 ecologically distinct groups, anomalous deaths, lack of recovery in both groups and other indirect evidence (see below) support this contention.

Table 4. Life stage and sex (if known), estimated age and year of death of AT1 whales during the 18 mo following the 'Exxon Valdez' oil spill. Abbreviations as in Table 1

\begin{tabular}{|lccccccccc|}
\hline Whale & AT5 & AT7 & AT8 & AT15 & AT16 & AT19 & AT20 & AT21 & AT22 \\
\hline Sex & ado & ado & ado & ado & ado & ado & & ado & \\
Died & 1990 & 1990 & 1990 & 1990 & 1990 & 1990 & 1990 & 1990 & 1990 \\
Age & 27 & 22 & 19 & 33 & 33 & 16 & 16 & 26 & 14 \\
\hline
\end{tabular}

\section{Whales in oil}

Killer whales from the AT1 Group were photographed in slicks of oil as early as $24 \mathrm{~h}$ after the spill. The slick resulting from the spill was several hundred kilometers long and moved southwest from its origin over several months, allowing an extended time and large geographic area for many cetaceans to come into contact with the oil. In the months following the spill, there were numerous observations of gray whales, harbor porpoises Phocoena phocoena, Dall's porpoises and killer whales swimming through light-to-heavy crude-oil sheens (Harvey \& Dahlheim 1994). One oilcoated Dall's porpoise appeared to be stressed, remaining at the surface for extended periods of time (Harvey \& Dahlheim 1994). Several days after the spill, a marine mammal biologist on an aerial reconnaissance flight observed gray whales swimming lethargically at the surface, and noted that oil fumes could be detected in the plane at an altitude of $200 \mathrm{~m}$ (J. Lentfer pers. comm. in Harvey \& Dahlheim 1994).

Traveling killer whales may spend 3 to 10 min at a time under water, and when they surface to breathe, they may have traveled hundreds of meters. Waves and darkness can reduce their visual ability at the surface. It is conceivable that whales could surface within a fresh slick and find it difficult to locate oil-free water, if they were able to detect the oil at all. During the Mega Borg oil spill, bottlenose dolphins apparently detected heavier slicks, although they did not necessarily avoid swimming into them (Smultea \& Wursig 1995). Additionally, killer whales begin to exhale before they surface, and may be committed to an inhalation despite the presence of oil (Matkin et al. 1999a). Our observations following the EVOS indicate that neither the AT1 Group nor AB Pod avoided the heavy sheens of oil or mousse.

\section{Synchonus decline}

The strongest evidence that the oil spill led to the mortalities in AB Pod and the AT1 Group is the synchronous nature of their sharp declines (Fig. 4) and the presence of the whales in or near oil slicks during the first 6 mo after the spill. The loss of $33 \%$ of AB Pod and $41 \%$ of the AT1 Group from the time of the spill through the following winter of 1989-1990 is a catastrophic event with no precedent in any population of killer whales in the North Pacific (Ford et al. 1998, 2000, Matkin et al. 1999a) and is well outside the normal range observed in other pods from the southern Alaska resident population. In view of the mor- 
tality patterns for AB Pod and the AT1 Group and other resident pods during the 21 yr study period, it is highly unlikely that this mortality was simply coincidental with the EVOS.

\section{Routes of exposure}

Though direct evidence from carcasses is missing, acute exposure and toxicity are indicated for several reasons. The oil was most volatile and produced the most aromatics in the weeks immediately following the spill (Spies et al. 1996), and inhalation of oil or concentrated aromatics is extremely toxic (Griffiths et al. 1987, Geraci 1990, Neff 1990). Cetaceans are obligatory surface breathers and the large quantities of monoaromatic hydrocarbons evaporating out of the oil slick would have been most concentrated immediately above the water's surface. Monoaromatics easily cross membranes in the lungs, and will be taken up rapidly, resulting in a narcosis response well documented in humans (Ainsworth 1960, Bass 1986). Griffiths et al. (1987) described the deaths of 7 dolphins caused by respiratory stress due to oil inhalation after a spill in the Arabian Sea. The fumes themselves may not have been directly lethal, but they could easily have caused marine mammals to lose consciousness and drown (St. Aubin \& Geraci 1994). The acute response could have happened in minutes if monoaromatic concentrations were high. We believe that the 7 animals missing when AB Pod was thoroughly photographed $6 \mathrm{~d}$ after the spill likely died as a result of inhaling oil or its vapors.

The effects of vapor or oil inhalation may range from instant death to sub-lethal damage to mild irritation, depending on concentration and length of exposure (Geraci 1990). If there were acute mortalities, then sub-lethal damage should have been prevalent as

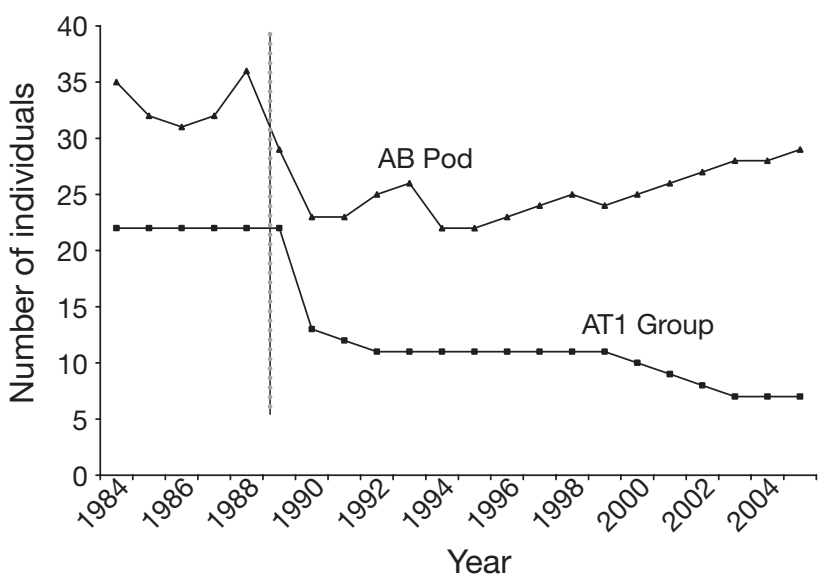

Fig. 4. Orcinus orca. Number of whales in AB Pod and AT1 Group 1984 to 2005 (vertical line: 'Exxon Valdez' oil spill) well. Inhaled hydrocarbons may inflame mucous membranes, cause lung congestion, lead to pneumonia and cause neurological damage and liver disorders (Geraci 1990, Neff 1990, Lipscomb et al. 1994). While the most acutely toxic compounds in crude oil volatize first, lethal effects may be experienced during the first month after a spill (Spies et al. 1996). In addition, the cold winter conditions of Prince William Sound in March were likely to slow the oil's weathering and evaporation processes (Morris \& Loughlin 1994).

Possible visual evidence of sub-lethal effects was the collapsed fins of the 2 males, AB2 and AB3. While common in captive killer whales, the phenomenon is rare in free-ranging animals (Matkin et al. 1999a). In over 2 decades, we have observed only 2 additional instances of completely collapsed dorsal fins in the other 10 resident pods.

The AT1 Group whales faced a second avenue for contact with oil, due to the prevalence of harbor seals in their diet (Saulitis et al. 2000). On heavily oiled sites in western Prince William Sound, $81 \%$ of the harbor seals were observed to be oiled (Lowry et al. 1994). Four months after the spill, an estimated 83 to $100 \%$ of seals were heavily oiled at several haul-outs around the north end of Knight Island in western Prince William Sound, areas where AT1 transients typically foraged for seals (Scheel et al. 2001). Oiled harbor seals were reported to be unusually lethargic and approachable (Lowry et al. 1994) and were likely easy prey for the whales. Brain lesions caused by oil exposure were documented in harbor seal carcasses and were suggested to explain the disorientation and lethargy observed (Spraker et al. 1994). By consuming oiled seals, AT1 whales could have experienced chronic exposure for several months after the spill. In 1990, AT1 whales were encountered more frequently in western Prince William Sound than in any other year of the study, where they were observed to prey primarily upon harbor seals (Matkin et al. 1999a, Saulitis et al. 2000).

According to Williams et al. (2004), an adult male killer whale would require the equivalent of one-third to one-half of an adult female sea lion (average weight $270 \mathrm{~kg}$ ) per day to satisfy its energetic requirements, which suggests that they would require roughly 1 or 2 adult harbor seals (66 to $89 \mathrm{~kg}$ ) per day. Geraci (1990) estimated that a long-finned pilot whale Globicephala melas would need to ingest 301 of oil over a period of weeks in order to suffer severe effects. Although the quantity of oil that would be associated with a fully oiled harbor seal has not been documented, a diet including heavily contaminated adult harbor seals could lead to the ingestion of a significant quantity of oil over time. The diet of contaminated prey would not account for acute mortalities immediately following the spill, but could result in sub-lethal damage over a 
period of months, eventually leading to lack of fitness and death.

Direct linkage to toxic oil exposure is lacking because there was no sampling of live killer whales, and the few autopsies done on stranded killer whales were incomplete and inconclusive. Since killer whales tend to sink when they die (Zenkovich 1938), the stranding of a killer whale carcass is a rare event. No carcasses were found until 1990, when 2 AT1 animals were examined, but the tissues were degraded, lungs were not evaluated, and individual identities could be determined in only one instance (Dahlheim \& Matkin 1994). The other 2 carcasses described by Dahlheim \& Matkin (1994), both transients, were recovered in 1991 and 1992, respectively (Heise et al. 2003). No evidence of oil in stomachs was found (Dahlheim \& Matkin 1994), but this would not be expected 2 and 3 yr after the oil spill. Respiratory tissues were not examined.

Thorough necropsies on other marine mammals, particularly sea otters Enhydra lutris, were more revealing. The exposure of otters to oil immediately following the spill resulted in the occurrence of interstitial pulmonary emphysema, gastric erosion and hemorrhage, hepatic and renal lipidosis, and centrilobular hepatic necrosis (Lipscomb et al. 1994). Although the mechanism could not be determined, oil exposure was found to compromise respiration through the development of pulmonary emphysema, and is consistent with acute exposure to oil vapors (Peterson et al. 2003). Although severely affected harbor seals died prior to the collection of animals for the study, Spraker et al. (1994) found 4 types of lesions characteristic of hydrocarbon toxicity in the brains, principally the thalamus, in oiled seals collected months after the spill.

\section{Fishery interactions}

In addition to the lack of evidence for oil spill injury from necropsies of dead killer whales, Dahlheim \& Matkin (1994) attributed their inability to unequivocally link the mortalities in AB Pod to the spill to possible long-line fishery interactions, which were a factor in increased mortalities in the mid-1980s. There is, however, nothing to suggest that fisheries interactions were a factor. None of the thousands of photographs in 1987 and thereafter detect any new bullet wounds. The fishery was not opened from fall 1988, when all 36 AB Pod whales were still alive, until June 1989, well after the disappearance of the first 7 whales. There was little interaction between killer whales and the longline fishery in years immediately following the spill, possibly due to change in season opening (C. O. Matkin unpubl. data). Although 3 AB Pod whales that had bullet wounds or possible wounds in 1985, and 1 whale that had wounds in 1986, died following the 1989 spill, it is unlikely that those 3 to $4 \mathrm{yr}$ old wounds were the cause of death, especially since in 3 of the animals the wounds were in the dorsal fin or high on the dorsal ridge. Photographs indicated that all bullet wounds appeared to be healed by 1988, except for one wound at the base of AB18's saddle patch. Although bullets have been found in necropsies of whales caught in British Columbia and Washington for display in aquaria, they have not been considered as the cause of death (Keyes, cited in Hoyt 1981, G. Ellis pers. comm.). In addition, fisheries interactions do not explain the mortalities of AT1 transients, which feed only on marine mammals (Saulitis et al. 2000) and appear to avoid vessels (C. O. Matkin unpubl. data). Given the lack of any new wounds after 1987, 2 yr prior to the spill, changes in prosecution of the fishery, and the lack of fishery interaction with the AT1 Group, it is highly unlikely that fishery interactions accounted for any deaths after 1987 in AB Pod or in the AT1 Group.

\section{Recovery following the spill}

Recovery of the AB Pod after 1990 was unexpectedly slow (it increased an average of $1.6 \%$ per year) compared to population increases in other resident pods in Prince William Sound (which increased an average $3.2 \%$ per year), and was the result of 2 factors: (1) abnormal mortalities of reproductive females and juveniles in the year following the spill; and (2) continued unexpected mortalities in years following the spill. Based on modeling of the southern Alaska resident population other than AB Pod, recruitment in AB Pod since the spill was considerably lower than expected due to the disproportionate loss of reproductive and juvenile females at the time of the spill and the resulting loss in long-term reproductive potential (Table 3, Fig. 2b). Although a juvenile of unknown sex and 2 older (probably post-reproductive) females were lost from $A B$ Pod during the period of interaction with the long-line fishery, the loss of reproductive potential was insignificant compared to the loss of 4 females and 8 juveniles following the spill. Killer whale mortality rates for reproductive animals and adolescents are generally very low (Olesiuk et al. 1990, 2005, Matkin et al. 2003).

The splitting off of the AB25 subpod may have been due to loss of closely related females that tied the 2 sub-pods together, as pods are composed of matrilines led by related females (Matkin et al. 1999b). However, the reason the subpod began traveling consistently with another pod (AJ Pod) is unprecedented and unexplained.

Thus, the recovery of AB Pod continues, although it is now the recovery of 2 functionally separate pods 
with a net growth lower in comparison to the rest of the southern Alaska resident population (Matkin et al. 2003). Without additional mortalities in the years after the spill and the disproportionate loss of females from the pod at the time of the spill, AB Pod should have recovered to pre-spill numbers by 2001 (Matkin et al. 2003). The exponential growth (3.2\%) of all pods other than AB Pod over the 21 yr study suggests that conditions in the northern Gulf of Alaska (including southeastern Alaska) have been near optimal for resident killer whales during the past 3 decades. This may be due in part to the significant rebound since the early 1970s of stocks of salmon, their primary prey (Saulitis et al. 2000). If this were not the case, the recovery of AB Pod would likely be even more protracted or might never occur.

The AT1 Group continues to decline long after the spill; factors in addition to the oil spill likely have impacted this socially and genetically isolated population for some time. No recruitment has been seen in the population since 1984 (Matkin et al. 1999b); nevertheless, the population was stable, with 22 whales from 1984 until the 9 mortalities in the fall/winter following the 1989 oil spill. While these mortalities included 2 older males, estimated ages (Table 4 ) indicate that the remainder were reproductive-age or juvenile whales. This contrasts with the deaths in the AT1 Group since 2000: 4 males estimated to be from at least 32 to over $40 \mathrm{yr}$ in age. The average age at death for male resident killer whales in Alaska is about $33 \mathrm{yr}$, as calculated from our life tables (C. O. Matkin unpubl. data).

Several factors, possibly acting in concert, have been suggested for the lack of recruitment in the AT1 Group, including high contaminant levels (Ylitalo et al. 2001) and the sharp decline of harbor seals in recent decades (Ver Hoef \& Frost 2003), a primary prey in Prince William Sound (Frost et al. 1999, Matkin et al. 1999a). Although the lack of recruitment may not be solely attributable to the oil spill, the mortality of additional males and reproductive-age females significantly reduced the potential for successful mating. Two potentially reproductive females that appeared to be nearly adult size at the beginning of the study, AT4 and AT18, remain, but the only surviving males may be too closely related to serve as breeding partners. Since neither of these females have produced viable calves, even though they are at least $30 \mathrm{yr}$ of age, future recruitment seems unlikely.

\section{CONCLUSIONS}

The results of this study underscore 3 key aspects of killer whale behavior and ecology that leave them highly vulnerable to natural or anthropogenic disasters such as oil spills. First, free-ranging killer whales do not or cannot detect or avoid crude oil sheens at the water's surface and are thus susceptible to inhalation of vapors and/or oil, skin contact, and, especially in the case of mammal-eating transients, to ingestion. Second, it is clear that resident killer whale pods, even under optimal conditions, may take decades to recover from the impacts of an oil spill or other disturbance, particularly if reproductive females and/or juvenile females are lost. Third, in a small, isolated and threatened population like AT1, a major environmental perturbation can greatly hasten the decline toward extinction.

It appears that AB Pod will eventually recover, over decades, to pre-spill numbers if recruitment rates remain positive and unexpected mortalities do not occur. However, there is no indication that the $2 \mathrm{AB}$ sub-pods will rejoin. The outlook for the AT1 Group is bleak and the group will likely go extinct within the next several decades.

Given the small numbers of individuals in these apex predator populations, their potential role in structuring ecological communities, and their cultural value to coastal residents, indigenous populations and visitors from around the world, the deaths in AB Pod and the impending extinction of the AT1 Group represent losses of and damage to resources of international ecological and cultural significance.

Acknowledgements. Funding for fieldwork was provided by the 'Exxon Valdez' Oil Spill Trustee Council and the Alaska Sea Life Center. With a study of this duration there were numerous individuals that gave extensive time and assistance in the many years of fieldwork. We sincerely thank them all. Additional photographic data for 1993 was supplied by M. Dahlheim at the National Marine Mammal Laboratory. P. Peterson, M. Dahlheim and J. Moran provided helpful reviews of the manuscript. The manuscript was substantially improved by the comments of 4 anonymous reviewers.

\section{LITERATURE CITED}

Ainsworth RW (1960) Petroleum vapor poisoning. Br Med J $1: 1547-1548$

Angliss RP, Outlaw RB (2006) Alaska marine mammal stock assessments 2006. NOAA Technical Memorandum NMFS-AFSC-168, National Marine Fisheries Service, Seattle, WA

Baird RW, Whitehead H (2000) Social organization of mammal-eating killer whales: group stability and dispersal patterns. Can J Zool 78:2096-2105

Balcomb KC, Boran JR, Heimlich SL (1982) Killer whales in Greater Puget Sound. Rep Int Whal Comm 32:681-686

Barrett-Lennard LG (2000) Population structure and mating patterns of killer whales, Orcinus orca, as revealed by DNA analysis. PhD thesis, University of British Columbia, Vancouver

Barrett-Lennard LG, Smith TG, Ellis GM (1996) A cetacean biopsy system using lightweight pneumatic darts, and its 
effect on the behaviour of killer whales. Mar Mamm Sci 12:14-27

Bass M (1986) Sniffing gasoline. JAMA 255:2604-2605

Bigg MA, Olesiuk PF, Ellis GM, Ford JKB, Balcomb KCB III (1990) Social organization and genealogy of resident killer whales (Orcinus orca) in the coastal waters of British Columbia and Washington State. Rep Int Whal Comm Spec Iss 12:386-406

Dahlheim ME, Matkin CO (1994) Assessment of injuries to Prince William Sound killer whales. In: Loughlin TR (ed) Marine mammals and the 'Exxon Valdez'. Academic Press, San Diego, CA, p 163-172

Evans W (1982) A study to determine if gray whales detect oil. In: Geraci JR, St. Aubin DJ (eds) Study on the effects of oil on cetaceans. Contract AA 551-CT9-22. Final report to U.S. Dept. of Interior, BLM, Washington, DC, p 47-61

Ford JKB, Ellis GM, Barrett-Lennard LG, Morton AB, Balcomb KC III (1998) Dietary specialization in two sympatric populations of killer whales (Orcinus orca) in coastal British Columbia and adjacent waters. Can J Zool 76: 1456-1471

Ford JKB, Ellis GM (1999) Transients: mammal-hunting killer whales. UBC Press, Vancouver

Ford JKB, Ellis GM, Balcomb KC III (2000) Killer whales, 2nd edn. University of British Columbia Press, Vancouver

Frost KJ, Lowry LF, Ver Hoef JM (1999) Monitoring the trend of harbor seals in Prince William Sound, Alaska, after the 'Exxon Valdez' oil spill. Mar Mamm Sci 15:494-506

Geraci JR (1990) Physiologic and toxic effects on cetaceans. In: Geraci JR, St. Daubin DJ (eds) Sea mammals and oil: confronting the risks. Academic Press, New York, p 167-197

Geraci JR, St. Aubin DJ (1985) Expanded studies on the effects of oil on cetaceans. Contract 14-12-0001-29169. Final Report for U.S. Dept. of Interior, Minerals Management Service, Washington, DC

Griffiths DJ, Oritsland NA, Oritsland T (1987) Marine mammals and petroleum activities in Norwegian waters. Fisken Havet 1:179

Harvey JT, Dahlheim ME (1994) Cetaceans in oil. In: Loughlin TR (ed) Marine mammals and the 'Exxon Valdez'. Academic Press, San Diego, CA, p 257-264

$>$ Heise K, Barrett-Lennard LG, Saulitis EL, Matkin CO, Bain D (2003) Examining the evidence for killer whale predation on Steller sea lions in British Columbia and Alaska. Aquat Mamm 29:325-334

Hoyt E (1981) The whale called killer. E. P. Dutton, New York Leatherwood S, Matkin CO, Hall JD, Ellis GM (1990) Killer whales, Orcinus orca, photo-identified in Prince William Sound, Alaska, 1976 through 1987. Can Field-Nat 104: 362-371

Lipscomb TK, Harris RK, Rebar AH, Bellachey BE, Haebler RJ (1994) Pathology of sea otters. In: Loughlin TR (ed) Marine mammals and the 'Exxon Valdez'. Academic Press, San Diego, CA, p 265-280

Loughlin TR (ed) (1994a) Marine mammals and the 'Exxon Valdez'. Academic Press, San Diego, CA

Loghlin TR (1994b) Tissue hydrocarbon levels and the number of cetaceans found dead after the spill. In: Loughlin TR (ed) Marine mammals and the 'Exxon Valdez'. Academic Press, San Diego, CA, p 359-370

Lowry LF, Frost KJ, Pitcher KW (1994) Observations of oiling in harbor seals in Prince William Sound. In: Loughlin TR (ed) Marine mammals and the 'Exxon Valdez'. Academic Press, San Diego, CA, p 209-226

Maniscalco JM, Matkin CO, Maldini D, Calkins DG, Atkinson S (2007) Assessing killer whale predation on Steller sea lions from field observations in Kenai Fjords, Alaska. Mar Mamm Sci 23:306-321

Matkin CO, Saulitis EL (1994) Killer whale (Orcinus orca) biology and management in Alaska. Contract T75135023, Marine Mammal Commission, Washington, DC

Matkin CO, Ellis GM, Dahlheim ME, Zeh J (1994) Status of killer whale pods in Prince William Sound 1984-1992. In: Loughlin TR (ed) Marine mammals and the 'Exxon Valdez'. Academic Press, San Diego, CA, p 141-161

Matkin CO, Matkin DR, Ellis GM, Saulitis E, McSweeney D (1997) Movements of resident killer whales in southeastern Alaska and Prince William Sound, Alaska. Mar Mamm Sci 13:469-475

Matkin CO, Ellis GM, Saulitis EL, Barrett-Lennard L, Matkin D (1999a) Killer whales of southern Alaska. North Gulf Oceanic Society, Homer, AK

Matkin CO, Ellis GM, Olesiuk P, Saulitis EL (1999b) Association patterns and genealogies of resident killer whales (Orcinus orca) in Prince William Sound, Alaska. Fish Bull 97:900-919

Matkin CO, Ellis GM, Barrett-Lennard LG, Yurk H and others (2003) Photographic and acoustic monitoring of killer whales in Prince William Sound and Kenai Fjords. 'Exxon Valdez' Oil Spill Restoration Project final report, North Gulf Oceanic Society, Homer, AK

Matkin D, Straley J, Gabrielle C (2007) Killer whale feeding ecology and non-predatory interactions with other marine mammals. In: Piatt JG, Gende SM (eds) Proc 4th Glacier Bay Sci Symp 2004. USGS, Juneau, AK, p 147-150

Morris BF, Loughlin TR (1994) Overview of the 'Exxon Valdez' oil spill, 1989-1992. In: Loughlin TR (ed) Marine mammals and the 'Exxon Valdez'. Academic Press, San Diego, CA, p 1-22

Neff JM (1990) Composition and fate of petroleum and spilltreating agents in the marine environment. In: Geraci JR, St. Aubin DJ (eds) Sea mammals and oil: confronting the risks. Academic Press, New York, p 1-33

Olesiuk PF, Bigg MA, Ellis GM (1990) Life history and population dynamics of resident killer whales (Orcinus orca) in the coastal waters of British Columbia and Washington State. Rep Int Whal Comm Spec Iss 12:209-243

Olesiuk PF, Ellis GM, Ford JKB (2005) Life history and population dynamics of northern resident killer whales (Orcinus orca) in British Columbia. CSAS Res Doc 2005/045. Fisheries and Oceans Canada, Nanaimo

Peterson $\mathrm{CH}$, Rice SD, Short JW, Esler D, Bodkin JL, Ballachey BE, Irons DB (2003) Long-term ecosystem response to the 'Exxon Valdez' oil spill. Science 302:2082-2086

Rice SD, Spies RB, Wolfe DA, Wright BA (eds) (1996) Proc Exxon Valdez Oil Spill Symp. Am Fish Soc, Bethesda, MD

Saulitis EL, Matkin CO, Heise K, Barrett Lennard L, Ellis GM (2000) Foraging strategies of sympatric killer whale (Orcinus orca) populations in Prince William Sound, Alaska. Mar Mamm Sci 16:94-109

Saulitis EL, Matkin CO, Fay FH (2005) Vocal repertoire and acoustic behavior of the isolated AT1 killer whale subpopulation in Southern Alaska. Can J Zool 83:1015-1029

Scheel D, Matkin CO, Saulitis EL (2001) Distribution of killer whale pods in Prince William Sound, Alaska over a thirteen-year period, 1984-1996. Mar Mamm Sci 17:555-569

Smith TR, Geraci JR, St. Aubin DJ (1983) Reaction of bottlenose dolphins, Tursiops truncatus, to a controlled oil spill. Can J Fish Aquat Sci 40:1522-1525

Smultea MA, Wursig B (1995) Behavioral reactions of bottlenose dolphins to the Mega Borg oil spill, Gulf of Mexico 1990. Aquat Mamm 21:171-181

Spies RB, Rice SD, Wolfe DA, Wright BA (1996) The effects of 
the 'Exxon Valdez' oil spill on the Alaskan coastal environment. Proc 'Exxon Valdez' Oil Spill Symp. 2-5 February, 1993, Anchorage, AK

Spraker TR, Lowry LF, Frost KJ (1994) Gross necropsy and histopathological lesions found in harbor seals. In: Loughlin TR (ed) Marine mammals and the 'Exxon Valdez'. Academic Press, San Diego, CA, p 281-312

St. Aubin DJ, Geraci JR (1994) Summary and conclusions. In: Loughlin TR (ed) Marine mammals and the 'Exxon Valdez'. Academic Press, San Diego, CA, p 381-386

Ver Hoef JM, Frost KJ (2003) A Bayesian heirarchical model for monitoring harbor seal changes in Prince William Sound, Alaska. Environ Ecol Stat 10:201-219

von Ziegesar OG, Ellis G, Matkin CO, Goodwin B (1986) Sightings of identifiable killer whales in Prince William Sound, Alaska 1977-1983. Cetus (6)2:9-13

von Ziegesar OC, Miller E, Dahlheim ME (1994) Impacts on humpback whales in Prince William Sound. In: Loughlin TR (ed) Marine mammals and the 'Exxon Valdez'. Academic Press, San Diego, CA, p 173-192

Editorial responsibility: Otto Kinne,

Oldendorf/Luhe, Germany
Vos DJ, Quakenbush LT, Mahoney BA (2006) Documentation of sea otters and birds as prey for killer whales. Mar Mamm Sci 22:201-205

Williams TM, Estes JA, Doak DF, Springer AM (2004) Killer appetites: assessing the role of predators in ecological communities. Ecology 85:3373-3384

Ylitalo GM, Matkin CO, Buzitis J, Krahn MM, Jones LL, Rowles T, Stein JE (2001) Influence of life-history parameters on organochlorine concentrations in free-ranging killer whales (Orcinus orca) from Prince William Sound, AK. Sci Total Environ 281:183-203

Yurk H (2005) Vocal culture and social stability in resident killer whales (Orcinus orca) of the Northeastern Pacific. $\mathrm{PhD}$ thesis, University of British Columbia, Vancouver

Yurk H, Barrett-Lennard LG, Ford JKB, Matkin CO (2002) Cultural transmission within maternal lineages: vocal clans in resident killer whales in southern Alaska. Anim Behav 63:1103-1119

Zenkovich BA (1938) On the Kosatka or whale killer (Grampus orca). Priroda 4:109-112 (Translated by L.G. Robbins)

Submitted: May 10, 2007; Accepted: September 28, 2007

Proofs received from author(s): March 14, 2008 